\title{
Review
}

\section{Genetic Counseling and Testing for Common Hereditary Breast Cancer Syndromes}

\author{
A Paper from the 2007 William Beaumont Hospital \\ Symposium on Molecular Pathology
}

\author{
Dawn C. Allain \\ From the Clinical Cancer Genetics Program and the Human \\ Cancer Genetics Program, Department of Internal Medicine, \\ Arthur G. James Cancer Hospital and Richard J. Solove Research \\ Institute, The Obio State University, Columbus, Obio
}

\begin{abstract}
Throughout the past 15 years, the identification of several genes associated with hereditary breast cancer has fueled the growth of clinical genetic counseling and testing services. In addition, increased knowledge of the genetic and molecular pathways of the known hereditary breast cancer genes, as well as an increased understanding of the impact of testing on individuals has added to the ability to identify, manage, and provide psychosocial support for mutation carriers. This review provides an overview of the clinical features, cancer risks, causative genes, and management for hereditary breast and ovarian cancer syndrome, Cowden syndrome, and Li-Fraumeni syndrome. This article summarizes the genetic counseling process and genetic test result interpretation, including a review of the key elements involved in the provision of risk assessment and informed consent, as well as a review of the risks, benefits, and limitations of cancer susceptibility genetic testing. $(\mathrm{J} \mathrm{Mol}$ Diagn 2008, 10:383-395; DOI: 10.2353/jmoldx.2008.070161)
\end{abstract}

Breast cancer affects one in eight women in the United States ${ }^{1}$ and is caused by an accumulation of mutations in genes that promote cell growth or maintain DNA integrity. ${ }^{2,3}$ The majority of breast cancer diagnoses are attributable to acquired somatic mutations; however, $\sim 5$ to $10 \%$ of all cases are caused by a mutation in a highly penetrant cancer predisposition gene. Individuals who carry a mutation in a cancer susceptibility gene have a significantly higher risk to develop breast cancer, as well as other cancers, depending on which gene is mutated. The ability to identify individuals with a hereditary predisposition for cancer provides the opportunity to educate the individual about personal and familial risk, and provide appropriate medical management.

\section{Hereditary Breast Cancer Syndromes}

Three of the most clearly described hereditary breast cancer syndromes are hereditary breast and ovarian cancer syndrome, Cowden syndrome, and Li-Fraumeni syndrome (LFS). All of these conditions are inherited in an autosomal dominant pattern, and are associated with other cancers and clinical features. Genetic testing for each of the genes associated with these syndromes is available through commercial and research laboratories, allowing health care providers the ability to offer clinical cancer genetic counseling and testing services to at-risk individuals.

\section{Hereditary Breast and Ovarian Cancer Syndrome (BRCA1 and BRCA2)}

Hereditary breast and ovarian cancer syndrome is associated with a significantly increased risk for breast cancer and ovarian cancer compared to the general population risk. Hereditary breast and ovarian cancer syndrome is caused by mutations in the BRCA1 and BRCA2 genes and is believed to account for the majority of hereditary

\footnotetext{
Accepted for publication May 23, 2008
}

This article is partly based on material presented by the author at the William Beaumont Hospital 16th Annual Symposium on Molecular Pathology: DNA Technology in the Clinical Laboratory, which took place on September 26 to 28, 2007 in Troy, MI.

Address reprint requests to Dawn C. Allain, M.S., CGC, Clinical Cancer Genetics Program, Human Cancer Genetics Program, Department of Internal Medicine, Arthur G. James Cancer Hospital and Richard J. Solove Research Institute, The Ohio State University, 2050 Kenny Rd., 8th Floor, Columbus, $\mathrm{OH}$ 43210. E-mail: dawn.allain@osumc.edu. 
breast and ovarian cancers. ${ }^{4-6}$ Women with mutations in the $B R C A 1$ or BRCA2 genes are estimated to have a 60 to $80 \%$ lifetime risk for breast cancer. ${ }^{7-9}$ A recent metaanalysis published by Chen and Parmigiani ${ }^{10}$ found a cumulative breast cancer risk to age 70 years to be $57 \%$ and $49 \%$ for BRCA1 and BRCA2 carriers, respectively. An earlier meta-analysis published by Antoniou and colleagues, ${ }^{7}$ found an average cumulative breast cancer risk in BRCA1 carriers by age 70 years of $65 \%$ and a $45 \%$ risk of breast cancer in BRCA1 carriers. Several studies have also indicated that women with BRCA mutations who have had breast cancer, have an $\sim 35$ to $43 \%$ lifetime risk, with some studies estimating up to a $64 \%$ lifetime risk, or a $3 \%$ risk per year, for developing a contralateral breast cancer. ${ }^{8,11-15}$ According to an early study, $57 \%$ of BRCA1 carriers are diagnosed with breast cancer under the age of 50 , compared with $28 \%$ of BRCA2 carriers. ${ }^{6}$ Men with BRCA2 mutations are estimated to have a $6 \%$ lifetime risk for breast cancer. ${ }^{16,17}$ Although breast cancer in men with BRCA1 mutations has been reported, the lifetime risk for male breast cancer associated with BRCA1 mutations is not well defined. ${ }^{15,18-20}$ A recent retrospective study by Tai and colleagues, ${ }^{21}$ estimate that male BRCA1 mutation carriers had a $1.2 \%$ risk for breast cancer by age 70 years.

Women who have a BRCA1 mutation have a 15 to $60 \%$ lifetime risk for ovarian cancer; and women with BRCA2 mutations have an estimated 10 to $27 \%$ cumulative risk. $^{7-10,22}$ Chan and Parmigiani's meta-analysis found a $40 \%$ and $18 \%$ cumulative risk for ovarian cancer by age 70 years in BRCA1 and BRCA2 carriers, respectively. In addition, women with BRCA2 mutations tend to develop ovarian cancer at an older age (after age 50) compared to those with BRCA1 mutations. ${ }^{10,22}$

Men and women with hereditary breast and ovarian cancer syndrome are also at risk for additional cancers. Several studies have found an association with BRCA mutations and increased risks for melanoma and cancers of the prostate and pancreas. ${ }^{17,23,24}$ The Breast Cancer Linkage Consortium found a an increased risk for prostate cancer in BRCA1 mutation carriers who were younger than 65 years of age [relative risk $(R R)=1.82$, $95 \%$ confidence interval $(\mathrm{Cl})=1.01$ to 3.29$]$, but not in men 65 years or older. ${ }^{23}$ Other studies looking specifically at male BRCA1 carriers have found a twofold to threefold increased risk for prostate cancer. ${ }^{8,23}$ The Breast Cancer Linkage Consortium identified a 4.65 relative risk for prostate cancer in male BRCA2 mutation carriers, corresponding to a $7.5 \%$ cumulative risk by age 70 years. ${ }^{25}$ Other studies have found a 19 to $39 \%$ risk of prostate cancer in BRCA2 carriers. ${ }^{18,25}$ Increased risk for pancreatic cancer in BRCA2 mutation carriers is well documented. The Breast Cancer Linkage Consortium data found a statistically significant increased risk for pancreatic cancer $(\mathrm{RR}=3.51,95 \% \mathrm{Cl}=1.87$ to 6.58$)$, giving a cumulative risk by age 80 years of $3.2 \%$ for men and a $2.3 \%$ risk for women. ${ }^{25}$ Another study estimated a $7 \%$ risk of pancreatic cancer before age 75 years in Ashkenazi Jewish carriers of the 6174delT mutation in the BRCA2 gene. ${ }^{26}$ The risk for pancreatic cancer in BRCA1 mutation carriers is not as well established, although the Breast Cancer Linkage Consortium data suggests a rel- ative risk of $2.25(95 \% \mathrm{Cl}=1.26$ to 4.06$)$ for pancreatic cancer in BRCA1 mutation carriers. ${ }^{23}$

Clinicopathological features of the breast and ovarian tumors in the BRCA spectrum are slowly emerging. BRCA1 breast cancers tend to be more frequently negative for estrogen receptor, progesterone receptor, and HER-2/Neu overexpression when compared with presumably nonhereditary breast cancers. ${ }^{27-29} B R C A 1$ breast tumors have also been found to be more frequently poorly differentiated. ${ }^{30}$ Invasive ductal carcinoma is the most common histological type identified in BRCA1 breast tumors, but there is also a higher incidence of medullary carcinoma when compared to BRCA2 breast cancers and non-BRCA1/BRCA2 breast tumors $\left(13 \%\right.$ versus $3 \%$ and $2 \%$, respectively). ${ }^{28}$ Unlike $B R C A 1$-associated breast cancers, there is a less distinct pathological phenotype for BRCA2 breast cancers. BRCA2associated breast cancers tend to be higher-grade tumors than sporadic breast cancers, but the association is not as strong as with BRCA1 breast cancers. ${ }^{27,28,31}$ The distribution of estrogen and progesterone receptor status in BRCA2 breast cancers is similar to that in sporadic cases. ${ }^{27,31}$ In regards to HER-2/Neu status of BRCA2-related cancers, one study found that HER-2 overexpression was similar to that in BRCA1 tumors, although it was not significantly different from control cases. ${ }^{27}$ However, another study found lack of HER2-Neu amplification or overexpression in 18 BRCA2 breast tumors, which was statistically different when compared to breast tumors from non-BRCA2-positive individuals. $^{32}$

There have been several studies that have looked at the pathological features of ovarian tumors from BRCA1 and BRCA2 carriers. Most of these studies have found that $B R C A 1$ - and BRCA2-associated ovarian cancers are primarily high-grade, advanced stage, serous tumors. ${ }^{33-36}$ Endometrioid histology is the next most common ovarian tumor pathology associated with BRCA-positive status. ${ }^{37}$ Mucinous ovarian tumors occur at a much lower frequency in BRCA carriers when compared to noncarriers. ${ }^{36,37}$ Borderline ovarian tumors have also been identified in BRCA carriers, although they also occur at a frequency lower than control populations. ${ }^{37,38}$

Family history is essential to clinically identifying individuals at risk for mutations in the BRCA genes. Hallmark characteristics include individuals who have a personal or family history of premenopausal breast cancer, multiple family members diagnosed with breast and/or ovarian cancer, multiple generations affected, the occurrence of male breast cancer, and descent from a population with high incidence of founder mutations, such as Eastern European (Ashkenazi) Jewish ancestry or Icelandic ancestry. Individuals who are identified as having a high likelihood of hereditary breast and ovarian cancer syndrome should be offered the option of genetic analysis of the BRCA genes.

BRCA1, located on 17q11, ${ }^{39}$ encodes a 1863-amino acid polypeptide. In contrast, $B R C A 2$, on 13q12-q13, is larger than BRCA1, encoding 3418 amino acids. ${ }^{39-42}$ Both $B R C A 1$ and $B R C A 2$ are tumor suppressor genes involved in DNA repair. ${ }^{43} B R C A 1$ has also been implicated in cell-cycle regulation, protein ubiquitylation, and chromatin remodeling. ${ }^{42}$ Mutations in BRCA1 and BRCA2 can occur anywhere 
along the genes. However, there are three well-known founder mutations that occur at a higher frequency in the Ashkenazi Jewish population (185delAG and 5382insC in BRCA1 and 6174delT in BRCA2). ${ }^{44}$ Additional founder mutations have been described in Icelandics, ${ }^{45,46}$ French Canadians, ${ }^{47,48}$ Dutch, ${ }^{49,50}$ and African Americans, among other populations. ${ }^{51,52}$ The majority of deleterious mutations identified to date are frameshift or nonsense mutations or large genomic deletions or duplications. ${ }^{53,54}$

Clinical management of BRCA1 and BRCA2 mutation carriers focuses primarily on breast and ovarian cancer risk. For breast cancer risk, it is recommended that women with BRCA mutations begin monthly breast self-examinations at 18 years of age and twice per year clinical breast examinations beginning at age 25. ${ }^{55,56}$ Annual mammography should begin at age 25 years, or 10 years earlier than the earliest breast cancer diagnosis in the family. ${ }^{56}$ In addition to annual mammography, the American Cancer Society recently published guidelines recommending that $B R C A$ carriers and first-degree relatives of BRCA carriers who do not know their own mutation status, also undergo annual breast magnetic resonance imaging screening. ${ }^{57}$ Although, the evidence supporting the efficacy of tamoxifen as a chemopreventive agent in BRCA carriers is limited, chemoprevention using tamoxifen, a selective estrogen receptor modulator, is also available to unaffected female BRCA carriers. Narod and colleagues ${ }^{58}$ found a $50 \%$ risk reduction for a contralateral breast cancer in affected BRCA1 and BRCA2 mutation-positive women who took tamoxifen, as did Gronwald and his colleagues. ${ }^{59}$ Risk-reducing mastectomy is appropriate on a case-by-case basis because several studies have shown a 90\% reduction (or up to a $95 \%$ risk reduction when the woman also has a concurrent or prior bilateral prophylactic mastectomy) in breast cancer risk in women with BRCA1/2 mutations who underwent bilateral prophylactic oophorectomy. ${ }^{60-62}$ Discussion of the benefits, limitations, and risks of mastectomy should include a thorough review of the degree of protection, reconstruction options, follow-up management recommendations, and potential psychological impact.

In women with BRCA mutations, risk-reducing salpingooophorectomy, ideally between the ages of 35 or 40 years, or on completion of child bearing, is recommended for ovarian cancer management. Several studies, both prospective and retrospective, have found an 80 to $96 \%$ ovarian cancer risk reduction with risk-reducing salpingo-oophorectomy. ${ }^{63-66}$ Risk-reducing salpingo-oophorectomy has also been shown to reduce the risk by up to $56 \%$ and $46 \%$, respectively, for developing breast cancer when performed in premenopausal BRCA1 and BRCA2 mutation carriers. ${ }^{67}$

Although the role of ovarian cancer surveillance has not been shown to lead to early detection or reduce mortality, for those individuals who do not elect prophylactic surgeries, concurrent transvaginal ultrasound, CA-125, and pelvic examination should be performed every 6 months beginning at 35 years of age, or 10 years earlier than the first ovarian cancer diagnosis in the family. ${ }^{55,56}$ In regards to chemoprevention, long term use of oral contraceptives has been shown to reduce the risk for ovarian cancer in women with BRCA mutations, ${ }^{68-71}$ with a study by Narod and col- leagues ${ }^{70}$ finding that the risk of developing ovarian carcinoma decreased $20 \%$ and $60 \%$ when used for up to 3 years or used for 6 or more years, respectively.

For male BRCA mutation carriers, monthly breast selfexamination, annual clinical breast examinations, and work-up of any suspicious breast lesions is warranted. The National Comprehensive Cancer Network guidelines also recommend that baseline mammogram be considered, with an annual mammogram if gynecomastia or parenchy$\mathrm{mal} / \mathrm{glandular}$ breast density is identified on baseline study. ${ }^{56}$ Some professionals have suggested that male BRCA carriers should begin prostate cancer surveillance at 40 years of age, rather than age 50 years. ${ }^{17}$ The National Comprehensive Cancer Network guidelines recommend that male BRCA mutation carriers should begin prostate screening with a digital rectal examination and PSA beginning at age 50, or earlier, based on the youngest age of diagnosis in the family.

\section{Cowden Syndrome (PTEN)}

Cowden syndrome, also known as multiple hamartoma syndrome, is characterized by the formation of multiple hamartomas that may develop in any organ, as well as an increase risk for carcinoma. ${ }^{72}$ Facial trichilemmomas, acral keratoses, and oral papillomatous papules are pathognomonic features. ${ }^{73,74}$ Greater than $90 \%$ of individuals with Cowden syndrome have been found to have mucocutaneous lesions. ${ }^{75}$ Women with Cowden syndrome have a 67 to $76 \%$ risk for benign breast disease, such as fibroadenomas and fibrocystic breast disease, and a 25 to $50 \%$ lifetime risk for breast cancer. ${ }^{72,76-78}$ Males with Cowden syndrome have also been described with breast cancer; however, a specific risk for male breast cancer has not been delineated. ${ }^{77,79}$

The lifetime risk for nonmedullary thyroid cancer, typically follicular and occasionally papillary, is $\sim 10 \%$. ${ }^{75}$ Benign thyroid disease, including multinodular goiter and adenomas are also more prevalent. ${ }^{72}$ Women have an increased risk for endometrial cancer (5 to 10\% estimated life time risk) and uterine fibroids. ${ }^{73,75}$ LhermitteDuclos disease, or dysplastic gangliocytoma of the cerebellum, is believed to be a major component of Cowden syndrome, but the incidence of this finding in Cowden's patients is, as yet, not known. ${ }^{75,80,81}$ Additionally, renal cell carcinoma has been added to the operational diagnostic criteria for Cowden syndrome; however, the risk for developing this lesion has not been well defined. ${ }^{73}$

Two studies by Schrager and colleagues ${ }^{82,83}$ studying the clinicopathological features of breast cancers associated with germline mutations in the PTEN gene found the usual spectrum of pathology, with infiltrating ductal cancer being the predominant invasive breast cancer. However, these two studies also identified a large spectrum of benign breast disease, including apocrine metaplasia, fibroadenomas, microcysts, adenosis, and hamartoma-like lesions with densely hyalinized collagen. ${ }^{82,83}$ This breast disease was reported to be bilateral and extensive.

Clinical diagnosis of Cowden syndrome is currently based on the operational criteria first developed by the 
Table 1. International Cowden Syndrome Consortium Operational Criteria for Diagnosis of Cowden Syndrome

\footnotetext{
Pathognomonic criteria (mucocutaneous lesions) Facial trichilemmomas

Acral keratoses

Papillomatous papules

Mucosal lesions

Major criteria

Breast cancer

Nonmedullary thyroid carcinoma, especially follicular thyroid cancer

Macrocephaly (occipital frontal circumference $\geq 95 \%$ )

Endometrial carcinoma

Lhermitte-duclos disease

Minor criteria

Other thyroid disease (eg, multinodular goiter or adenoma)

Mental retardation (IQ $\leq 75)$

Gastrointestinal hamartomas

Fibrocystic breast disease

Lipomas

Fibromas

Genito-urinary tumors (eg, renal cell carcinoma)

Genito-urinary malformations

Uterine fibroids

Operational diagnosis in an individual, any single pathognomonic criterion, but

1. Mucocutaneous lesions alone if there are:

a. Six or more facial papules, three or more of which must be trichilemmoma, or

b. Cutaneous facial papules and oral mucosal papillomatous, or

c. Oral mucosal papillomatosis and acral keratoses, or

d. Six or more palmoplantar keratoses

2. Two major criteria, but one must include macrocephaly or LDD

3. One major and three minor criteria, or

4. Four minor criteria

Operational diagnosis in a family member with a known diagnosis of Cowden syndrome in the family

5. A pathognomonic criterion

6. Any one major criterion with or without a minor criteria

7. Two minor criteria
}

See Eng. ${ }^{73}$

International Cowden Consortium in 1995 and adopted by the National Comprehensive Cancer Network Genetics/ High Risk Cancer Surveillance Panel. ${ }^{56}$ According to these operational criteria, to be diagnosed with Cowden syndrome an individual must exhibit a certain number of major or minor criteria. ${ }^{56,73}$ These criteria are summarized in Table 1. Approximately $80 \%$ of individuals who meet these strict operational diagnostic criteria have an identifiable PTEN mutation. $^{73,84,85}$

PTEN, a tumor suppressor gene located on chromosome 10 , encodes a 403-amino acid dual specificity phosphatase with lipid and protein substrates. ${ }^{86-88}$ The PTEN protein plays a role in numerous molecular pathways involving cell cycle arrest and/or apoptosis. ${ }^{89,90}$ Mutations in the PTEN gene are also associated with Bannayan-Riley-Ruvalcaba syndrome, Proteus syndrome, and Proteus-like syndrome. These diseases, along with Cowden syndrome, comprise what is referred to as the PTEN hamartoma tumor syndrome. ${ }^{89,91,92}$

Women who have Cowden syndrome should perform monthly breast self-examinations beginning at 18 years of age. They also require semiannual clinical breast ex- aminations beginning at age 25 years (or 10 years earlier than the earliest breast cancer diagnosis in the family). Although it is possible that the underlying fibroadenomas and fibrocystic breast disease seen in women with Cowden syndrome may impair the sensitivity of breast imaging, expert opinion recommends that imaging with annual mammography begin around age 30 to 35 years, or 5 to 10 years earlier than the earliest breast cancer diagnosis in the family. ${ }^{56,75}$ As with BRCA carriers, the American Cancer Society recommends annual breast magnetic resonance imaging screening for individuals with Cowden syndrome and their first-degree relatives. ${ }^{57}$ Riskreducing mastectomy is an individual choice and should be discussed on a case-by-case basis with each patient. Although recommendations regarding breast cancer surveillance in males have not been published, if a male with Cowden syndrome develops any palpable breast lesions, it would be prudent to perform a diagnostic evaluation for breast cancer. Endometrial carcinoma screening with blind endometrial aspirations should be performed annually in premenopausal females starting at age 35 to 40 years (or 5 years before the earliest endometrial cancer diagnosis in the family), and annual endometrial ultrasonography in postmenopausal women. ${ }^{56}$

Both men and women with Cowden syndrome should obtain a baseline thyroid ultrasound at 18 years of age, and an annual thyroid examination thereafter. ${ }^{56,75} \mathrm{An}$ annual urinalysis, with consideration to annual urine cytology and renal ultrasound, should be performed in both men and women if there is a family history of renal carcinoma. ${ }^{56,75}$ Additionally, men and women should undergo annual physical examinations beginning at 18 years of age, and a yearly dermatological evaluation may be justified. ${ }^{75}$

\section{LFS (TP53 and CHEK2)}

LFS is a rare cancer predisposition syndrome estimated to account for $\sim 1 \%$ of hereditary breast cancer. ${ }^{93}$ LFS is characterized by early-onset breast cancer, soft-tissue sarcomas, osteosarcomas, leukemias, brain tumors, and adrenocortical tumors. ${ }^{94-98}$ In families with LFS, soft-tissue sarcomas, brain tumors, and adrenocortical carcinomas are known to present in early childhood. ${ }^{95}$ Additionally, cancer of the lung, stomach, ovary, colon, pancreas, melanoma, and even Wilms' tumor, among other cancers, have been reported in Li-Fraumeni families. ${ }^{98-101}$

Several studies have attempted to delineate the cancer risk associated with LFS. A study of LFS relatives in 159 extended families found that the risk for developing cancer among carriers was $12 \%, 35 \%, 52 \%$, and $80 \%$ by $20,30,40$, and 50 years of age, respectively. ${ }^{102}$ Another study found a 50\% risk for cancer by age 40 and a 90\% risk by age $60 .{ }^{103}$ The risk for developing multiple primary cancers is also increased in LFS individuals; one study ${ }^{104}$ Additionally, after adjusting for gender-specific cancers, the cancer risk between the sexes is still significantly different, with LFS females having a greater risk of developing cancer (nearly 100\%) than males (73\%). ${ }^{102,105}$ In regards to breast cancer risk, a woman with LFS has a breast cancer risk of $56 \%$ by age 45 and greater than 
Table 2. Criteria for Li-Fraumeni Syndrome

Classic Li-Fraumeni syndrome ${ }^{94}$

- Proband with sarcoma diagnosed $\leq 45$ years, and

- First-degree relative with any cancer diagnosed $\leq 45$ years, and

- Another first- or second-degree relative in the same lineage diagnosed $\leq 45$ years with any cancer or a sarcoma at any age

Li-Fraumeni-like syndrome (Birch et $\mathrm{al}^{107}$ )

- Proband with any childhood cancer, sarcoma, brain tumor, or adrenocortical tumor diagnosed $\leq 45$ years, and

- A first- or second-degree relative with a typical Li-Fraumeni syndrome cancer (breast cancer, sarcoma, brain tumor, adrenocortical tumor, or leukemia) at any age, and

- A first- or second-degree relative with any cancer younger than the age of 60 years

Li Fraumeni-like syndrome (Eeles ${ }^{108}$ )

- Two first- or second-degree relatives with LFSrelated tumor (sarcoma, breast cancer, brain tumor, adrenal cortical tumor, or acute leukemia) diagnosed at any age

Chompret criteria ${ }^{109}$

- One first- or second-degree relative with cancer diagnosed before the age of 46

- Multiple primary tumors in the proband, regardless of family history

$90 \%$ by age 60 , with most diagnoses of breast cancer occurring under the age of $40 . .^{101,105,106}$

$\mathrm{Li}$ and Fraumeni and colleagues ${ }^{94}$ developed the first clinical diagnostic criteria for LFS, based on their study of 24 LFS kindreds, and this criteria has come to be known as the classic or strictest diagnostic criteria (Table 2). In an attempt to determine who to test for germline mutations associated with LFS, other groups loosened Li and Fraumeni and colleagues ${ }^{94}$ strict criteria, developing criterion for Li-Fraumeni-like (LFL) syndrome. LFL, as described by Birch and colleagues, ${ }^{107}$ is a proband with any childhood cancer or sarcoma, brain cancer, or adrenocortical carcinoma diagnosed by age 45 , who has a first-degree or second-degree relative with a typical LFS cancer at any age, and another first-degree or seconddegree family member with cancer diagnosed before the age of 60 . Another definition for LFL, published a year after Birch's definition, is even less strict, as illustrated in Table 2. ${ }^{108}$ More recently, Chompret and colleagues ${ }^{109}$ in 2001 recommended that genetic testing for TP53 mutations should be considered in families who meet the following criteria: a proband affected by a sarcoma, brain tumor, breast cancer, or adrenocortical cancer before age 36 years of age, with at least one first- or seconddegree relative with cancer (other than breast cancer if the proband has breast cancer) before age 46 years of age, or, a relative with multiple primary tumors at any age.

Mutations in TP53 are the primary cause of LFS. ${ }^{97,107,110,111}$ The TP53 gene is a well-known tumor suppressor gene, located on chromosome 17p13.1. Dubbed the "guardian of the genome," TP53 is associated with cell-cycle control and apoptosis. ${ }^{112,113}$ The TP53 gene has one noncoding and 10 coding regions with five highly conserved domains. ${ }^{114}$ The core DNA-binding areas are found in domains II to IV, and domain I is responsible for transacti- vation properties. ${ }^{115}$ The majority (70 to $80 \%$ ) of the mutations identified in the TP53 gene are located in exons 5 through $8 .{ }^{111,116,117}$ In families who meet the classical LFS diagnostic criteria, 50 to $70 \%$ have an identifiable TP53 mutation. ${ }^{107,109,115,116,118}$ In families who do not meet the strict diagnostic criteria, the likelihood of identifying a TP53 mutation is lower. ${ }^{107,109,115,118}$ Specifically, using the Birch and the Eeles LFL criteria, the mutation detection rate is estimated to be 21 to $40 \%$ and $8 \%$, respectively. ${ }^{111,119,120}$ Using Chompret and colleagues criteria, ${ }^{109}$ mutations in TP53 will be identified $20 \%$ of the time. ${ }^{109}$

Germline mutations in CHEK2 have also been attributed to several families with classic LFS and Li-Fraumenilike syndrome. ${ }^{120-124}$ CHEK2, located on chromosome 22q12.2, codes for a serine/threonine protein kinase, which phosphorylates p53, leading to cessation of mitosis and allowing DNA repair. ${ }^{125}$ The CHEK2 protein also binds to and regulates the BRCA1 gene product. ${ }^{126}$ It is believed, therefore, that germline CHEK2 mutations disrupt a cell cycle checkpoint impairing the cell's ability to stop mitosis and repair DNA damage. ${ }^{122,123}$ Two mutations, the 1100delC mutation, a frameshift mutation that results in a premature stop codon, and R145W have both been identified in LFS families. ${ }^{121-123}$ However, one study assessed 15 individuals who met the LFS or LFL criteria and had tested negative for deleterious mutations in the TP53 gene; all were negative for the CHEK2 1100 delC mutation, ${ }^{127}$ suggesting that this mutation is not thought to play a significant role in LFS.

Management of individuals at-risk for LFS, or with a known germline mutation, is difficult because of the diverse array of tumors associated with the condition, as well as the paucity of proven ways to detect tumors early. Current guidelines suggest that women begin monthly breast self-examinations beginning at age 18 years and semiannual clinical breast examinations starting at 20 to 25 years of age (or 5 to 10 years before the earliest breast cancer diagnosis in the family). ${ }^{56}$ Given the evidence that ionizing radiation increases the risk of cancer in LFS carriers, ${ }^{104,128,129}$ there has been concern raised about the use of mammography as a breast cancer screening tool. ${ }^{104,115,129}$ However, current recommendations call for annual mammography and breast magnetic resonance imaging beginning at age 20 years, or earlier depending on the youngest breast cancer diagnosis in the family. ${ }^{56,57,115}$ Options for risk-reducing mastectomy should be discussed because some women with LFS may elect to pursue this procedure. Annual clinical evaluation is recommended, including careful dermatological and neurological examinations. ${ }^{56,115}$ Varley and colleagues ${ }^{115}$ also recommend an annual abdominal ultrasound and full blood count for children with LFS. Selective organ-targeted screening, based on individual family histories may be warranted, such as brain magnetic resonance imaging for those families with a history of brain tumors, ${ }^{56,115}$ although there is no published data supporting the efficacy of this approach. Additionally, the National Comprehensive Cancer Network guidelines recommend considering a colonoscopy every 2 to 5 years. 


\section{Genetic Counseling and Testing}

The process of genetic counseling facilitates informed, personally-driven, decision-making, which is integral to cancer susceptibility gene testing. The purpose of genetic counseling in the oncology setting is to allow individuals an opportunity to learn how heredity contributes to cancer risk, understand their personal risk of developing cancer, understand their options for managing their cancer risk, choose a course of action that is appropriate for them, and provide them with additional resources. ${ }^{130,131}$ The health care professionals who provide cancer risk assessment and genetic counseling must be well prepared to meet the needs of their clients. The ability to obtain and interpret family histories, provide personalized risk assessments, educate individuals about basic concepts in cancer susceptibility, facilitate client decision-making, discuss potential medical management recommendations, and address psychosocial concerns are necessary skills for health care professionals who provide cancer genetic counseling services. ${ }^{131}$ In addition, it is critical that health care professionals who are providing cancer genetic testing services be prepared to facilitate the dissemination of genetic testing information to family members because this is integral to identifying and managing at-risk individuals.

\section{Family History}

The key to identifying individuals who will benefit from genetic testing for hereditary cancer susceptibility genes lies in the risk assessment process. The first step in this process is to obtain and analyze a complete and accurate family history. Pedigrees should include detailed medical, health, and psychosocial history on the client (proband), as well as their first-, second-, and, if possible, third-degree maternal and paternal relatives (ie, children, parents, siblings, grandparents, aunts/uncles, and first cousins). ${ }^{132}$ Pedigrees should also include the type of cancer, age at diagnosis, and age at death for each affected individual related to the proband, as well as information about family members unaffected by cancer. ${ }^{130}$ Inquiries must include both maternal and paternal histories to determine from which side of the family the inherited susceptibility is being transmitted. Additionally, it is necessary to know the client's ancestry/ethnicity because some cancer susceptibility mutations have a higher prevalence in select populations.

Errors in family history reporting are well documented in the medical literature; therefore, accurate cancer risk assessment often requires confirmation of diagnosis through review of medical records or death certificates in some family members. ${ }^{133-135}$ In addition, family history is not static and should be updated on a regular basis because new diagnoses of cancer cases in families may alter genetic risk assessment. ${ }^{136}$ Physical examinations of family members may also assist in the identification of cancer susceptibility syndromes, such as Cowden syndrome.

\section{Education and Risk Assessment}

Analysis and interpretation of family history allows for personalized risk assessment. Several different risk estimates, such as the risk for developing cancer or the likelihood of a genetic mutation in the family, may be provided to an individual during the counseling process. ${ }^{130}$ Risk models calculating the likelihood of developing breast cancer use several different factors. The model of Gail and colleagues ${ }^{137}$ estimates breast cancer risk by taking into account a woman's age at menarche, age at first live birth, number of first-degree relatives with breast cancer, and previous biopsies, with specific focus on whether there was presence of atypical hyperplasia. The model of Gail and colleagues ${ }^{137}$ will underestimate the risk of developing breast cancer if a woman is a carrier of a cancer susceptibility gene mutation and if the woman has a paternal history of cancer. Thus, in the context of cancer genetic risk assessment, the model of Gail and colleagues ${ }^{137}$ is more often used to provide breast cancer risk estimates to individuals who do not have family histories suggestive of a hereditary breast cancer syndrome or who have tested negative for a known familial mutation. The model of Gail and colleagues ${ }^{137}$ is also used to counsel women about the use of tamoxifen, as a chemopreventive agent. The tables of Claus and colleagues ${ }^{138}$ also determine breast cancer risk, taking into consideration the number and age of first- and second-degree female relatives with breast cancer. Despite this, the tables of Claus and colleagues ${ }^{138}$ will also underestimate the risk of a woman developing breast cancer if she has a hereditary predisposition to developing breast cancer. Again, when used in the provision of cancer risk assessment and counseling, the tables of Claus and colleagues ${ }^{138}$ are a helpful tool to provide a breast cancer risk estimate for a woman whose family history is not highly suggestive of a known hereditary cancer syndrome.

A second group of models (BRCAPRO, Myriad II, Penn II, BOADICEA, Tirer-Cuzick, Couch, and ShattuckEidens) are designed to estimate the likelihood of identifying a mutation in the BRCA1 or BRCA2 genes. ${ }^{5,139-142}$ These models have strengths and limitations that health care providers need to be familiar with to use and interpret them appropriately. ${ }^{14-145}$ For example, the Couch and colleagues $^{140}$ and Shattuck-Eidens and colleagues ${ }^{141}$ models use summarization of family history to estimate the likelihood that an individual carries a mutation in the BRCA1 gene, and do not estimate the chance of a BRCA2 mutation. The BRCAPRO model evaluates the probability that an individual is a carrier of a $B R C A$ mutation using family history and Bayes' theorem. ${ }^{139}$ However, BRCAPRO only incorporates relevant family history up to the second degree relatives, thereby, potentially underestimating the probability of BRCA mutations in individuals with an extended family history. The BRCAPRO model also does not incorporate pancreatic or prostate cancer risk into its risk estimate, thereby, leading to an underestimate of risk. There are currently no statistical models that predict the likelihood of identifying mutations in the PTEN or TP53 genes.

When using these risk models it is important for to remember that risk calculations may vary because of the 
different factors assessed, and clients should be educated about the limitations of these risk calculations so that they can put their risk estimates into context. Therefore, the health care provider should use clinical judgment so clients receive the most precise risk assessment.

Assessing psychosocial issues is integral to how we relay risk information. By identifying and analyzing the psychosocial issues during the cancer genetic counseling process, the health care provider can appreciate the different aspects of an individual's background, which affects their risk perception. ${ }^{146,147}$ Identifying the psychosocial issues may also help the health care provider and the client understand how an individual's emotions and psychosocial factors impact the utilization of the information presented during a genetic counseling session. ${ }^{146,148,149}$ In addition, recognizing the psychosocial factors at play allow a health care professional to provide anticipatory guidance.

\section{Genetic Testing}

Molecular analysis of the BRCA1, BRCA2, PTEN, and TP53 genes is commercially available, and it is well established which patients should be offered genetic testing for the conditions associated with mutations in these genes. According to the American Society of Clinical Oncology, ${ }^{150}$ individuals should be offered testing when they have a personal or family history suspicious for a cancer predisposition syndrome, the test results can be adequately interpreted, and the results will assist in the diagnosis or influence medical management of the individual or their at-risk family members. Pre- and posttest education and informed consent should be part of the genetic testing process for hereditary cancer susceptibility conditions. ${ }^{130,150,151}$ The process of genetic counseling allows individuals ample opportunity to educate themselves about the benefits, limitations, and risks of genetic testing, as well as the possible benefits and risks of cancer early detection and prevention strategies, to make an informed decision. In addition, although initially it is one individual being tested, individuals are encouraged through genetic counseling to consider how results from testing might affect not only them personally, but their family members as well. Individuals can also begin to plan how they will use results to influence their medical management and health behaviors.

Ideally, genetic testing should be performed on an individual who has been diagnosed with cancer because it provides the most information for the entire family. There are four possible test outcomes: positive (deleterious), true-negative, uninformative, and a variant of uncertain significance (Table 3). True-positive results are deleterious mutations that prevent normal gene function. A positive result confirms the diagnosis of a hereditary cancer syndrome and confers an increased risk for the cancers associated with the condition. At-risk family members can undergo genetic analysis for the specific mutation identified in the family to determine their risk status, and such testing will be highly sensitive.
Table 3. Genetic Test Results

\begin{tabular}{|c|c|}
\hline Result & Interpretation \\
\hline $\begin{array}{l}\text { True positive } \\
\text { (deleterious) }\end{array}$ & $\begin{array}{l}\text { Mutation identified is associated } \\
\text { with increased cancer risk }\end{array}$ \\
\hline True negative & $\begin{array}{l}\text { No mutation was identified in an } \\
\text { individual who has a known } \\
\text { deleterious mutation in the family. } \\
\text { Therefore, this individual is not at } \\
\text { an increased risk for developing } \\
\text { cancer }\end{array}$ \\
\hline Uninformative & $\begin{array}{l}\text { No mutation has been identified and } \\
\text { a deleterious mutation has not been } \\
\text { previously identified in the family. } \\
\text { The individual and family members } \\
\text { may still be at increased risk for } \\
\text { cancer and medical recommendations } \\
\text { should be based on family history }\end{array}$ \\
\hline $\begin{array}{l}\text { Variant of } \\
\text { uncertain } \\
\text { significance }\end{array}$ & $\begin{array}{l}\text { Mutation identified but its clinical } \\
\text { significance is not known. The } \\
\text { individual and family members may } \\
\text { still be at increased risk for cancer } \\
\text { and medical recommendations } \\
\text { should be based on family history }\end{array}$ \\
\hline
\end{tabular}

A true-negative result can occur only when there is a known deleterious mutation in the family. For example, an individual is found not to have the BRCA1 mutation previously identified in her father. Individuals with true-negative results are not at an increased risk for developing the cancers associated with the hereditary cancer syndrome. Instead, their risk for developing cancer is believed to be the same as that in the general population. There is data from a few studies, both prospective and retrospective, suggesting that individuals who test negative for known familial mutations in cancer susceptibility genes could still be at increased risk for cancers, attributed to shared genetic modifiers, when compared to the general population. ${ }^{152-154}$ However, it is important to note that the significant findings of increased risk were derived from retrospective data that may be subject to ascertainment bias and prospective data that did not reach statistical significance because of small sample sizes. Thus, more data are necessary to confirm these findings, as, if true, it could impact the management for these individuals.

Because some affected family members may be deceased or unwilling to undergo testing, it is not always feasible to test an affected family member. In other situations, an individual may chose to undergo genetic testing without knowing their family history, as in cases of adoption, or because of high cancer anxiety. In this scenario, a negative genetic test result does not exclude the possibility of a hereditary cancer predisposition. First, given limitations in current testing technology, a negative result does not exclude the possibility that there is an undetectable mutation in the gene being analyzed.53 Second, a negative result in this situation also does not exclude the possibility that the person may carry a mutation in a different cancer susceptibility gene that has not yet been tested. Counseling of individuals in this situation must stress that they still have a residual risk for developing cancer so that individuals do not have a false 
sense of reassurance. Third, it is possible that the unaffected family member does not carry a potentially identifiable deleterious mutation that is placing other family members at risk.

Variants of uncertain significance (VUS) are typically missense mutations that are of unknown functional significance and intronic mutations not known to be involved in mRNA processing. ${ }^{130,155}$ Thus, the risk consequences of VUS are often unknown. With BRCA1 and BRCA2 alone, it is estimated that VUS are identified in 10 to $13 \%$ of individuals who undergo full sequence analysis. ${ }^{20,155}$ The incidence of VUS in TP53 and PTEN is not well defined. VUS can occur in individuals who are affected with cancer, as well as those who are unaffected. In addition, the likelihood of identifying a VUS varies by ethnicity. Testing may be performed to determine whether the VUS tracks with the cancer in the family; however, without a functional assay to determine the implication of the gene change, the significance of the mutation remains unknown. ${ }^{5,53}$ In cases in which a VUS is identified, predictive testing for at-risk family members cannot be performed. Additionally, medical management must be based on the known family history rather than the presence or absence of the VUS.

\section{Benefits, Risks, and Limitations of Genetic Testing}

Individuals undergoing cancer genetic counseling must understand the benefits, limitations, and risks of genetic testing to make an informed decision about whether to use testing. The potential impact on medical management is an obvious benefit. A woman who tests positive for a known familial gene mutation can make informed decisions about when she should start cancer surveillance, the type of cancer surveillance necessary, and whether she should consider prophylactic surgeries. A woman with a true negative result can avoid unnecessary screening and/or surgeries. Genetic testing can clarify risk status, not only for the person being tested, but for other family members. If a deleterious mutation is identified, it allows for targeted mutation testing in at-risk family members. Genetic test results may also allay emotional and psychological fears associated with the uncertainty surrounding their risk status before undergoing genetic testing. ${ }^{156}$

Individuals should also be apprised of the limitations to genetic testing. As discussed previously, a negative result in an individual without cancer and without a known mutation in the family does not rule out a hereditary cancer syndrome in the family or the individual being tested. A family history of cancer could also be attributable to a gene that was not tested or a gene in which testing is not yet available. Inaccurate family history may also lead to inappropriate genetic testing which limits the accuracy of the result interpretation and risk assessment. In addition, individuals undergoing genetic testing may not have a detectable mutation based on current technological limitations.

Although the majority of the literature assessing the psychological impact of cancer genetic testing has not demonstrated any significant long-term negative consequences, several research studies have documented that individuals who undergo cancer susceptibility testing experience a range of emotions, including anxiety, distress, and depression. ${ }^{147,149,157-160}$ Guilt is another powerful emotional response individuals may experience, arising from the fear of passing the mutation on to one's children. ${ }^{161}$ In addition, some individuals experience guilt for not inheriting a mutation that has been identified in another family member. ${ }^{147,149,158,162}$ Family systems may be disrupted because some individuals will want the information genetic counseling and testing can offer and others will not. In some families, affected individuals may feel coerced into undergoing genetic testing to aid in determining the risk status of other family members. ${ }^{131}$ This disruption may occur not only between parents, children, and siblings, but also between spouses and partners. ${ }^{147}$

Genetic testing also has economic risks associated with it because the cost for testing can range from a few hundred dollars to more than $\$ 3000$ depending on the genes being tested and the type of testing being performed (targeted mutation analysis versus full sequencing). Although the majority of health insurance companies are covering the costs of genetic testing, some may not reimburse for counseling or testing services. Some insurance companies may only cover a portion of the cost. Individuals considering testing may want to consider determining their level of insurance coverage before proceeding with testing. ${ }^{130}$ In addition, when insurance coverage is broached, it may be necessary to address concerns regarding potential insurance discrimination. Although, to date, there is no published documentation of insurance discrimination for hereditary cancer syndrome testing, some individuals are still concerned. ${ }^{163}$ Fear of insurance discrimination can be so powerful that individuals may not pursue genetic testing or delay the testing. ${ }^{164}$ Pretest genetic counseling should, therefore, include a discussion about the lack of documented discrimination cases. Counseling should also include a review about the current federal legislation providing protection against genetic discrimination in health insurance, such as the Federal Health Insurance Portability and Accountability Act of 1996, which prevents group health plans from using genetic information as a pre-existing condition to limit or deny coverage, ${ }^{130,165}$ and the state laws regarding health insurance discrimination, keeping in mind that these laws vary from state to state. ${ }^{130}$

\section{Summary}

Only 5 to $10 \%$ of breast cancer cases are attributable to highly penetrant Mendelian cancer susceptibility genes. Currently, hereditary breast and ovarian cancer syndrome, LFS, and Cowden syndrome are the most common conditions being tested for in the clinical setting for individuals with personal or family histories of breast cancer. Identification of those individuals who would benefit from genetic testing still relies primarily on interpretation of a thorough family history, although pathological features of cancers may assist in risk assessment. Genetic 
counseling for these hereditary breast cancer syndromes is the standard of care and includes the process of obtaining informed consent through a thorough discussion of the risks, benefits, and limitations of risk assessment, genetic testing, result interpretation, and medical management options. Ultimately, genetic testing can assist in the identification of at-risk individuals who could benefit from improved medical management.

\section{References}

1. Ries L, Harkins D, Krapcho M, Miller B, Feuer E, Clegg L, Horner M, Howlader N, Eisner M, Reichman M, Edwards BE: SEER Cancer Statistics Review, 1975-2004. Rockville, National Cancer Institute, 2006

2. Feuer EJ, Wun LM, Boring CC, Flanders WD, Timmel MJ, Tong T: The lifetime risk of developing breast cancer. J Natl Cancer Inst 1993, 85:892-897

3. Fearon ER, Vogelstein B: A genetic model for colorectal tumorigenesis. Cell 1990, 61:759-767

4. Frank TS: Hereditary risk of breast and ovarian carcinoma: the role of the oncologist. Oncologist 1998, 3:403-412

5. Frank TS, Manley SA, Olopade OI, Cummings S, Garber JE, Bernhardt B, Antman K, Russo D, Wood ME, Mullineau L, Isaacs C, Peshkin B, Buys S, Venne V, Rowley PT, Loader S, Offit K, Robson M, Hampel H, Brener D, Winer EP, Clark S, Weber B, Strong LC, Rieger $P$, McClure M, Ward B, Shattuck-Eidens D, Oliphant A, Skolnick M, Thomas A: Sequence analysis of BRCA1 and BRCA2: correlation of mutations with family history and ovarian cancer risk. J Clin Oncol 1998, 16:2417-2425

6. Ford D, Easton DF, Stratton M, Narod S, Goldgar D, Devilee P, Bishop DT, Weber B, Lenoir G, Chang-Claude J, Sobol H, Teare MD, Struewing J, Arason A, Scherneck S, Peto J, Rebbeck TR, Tonin P, Neuhausen S, Barkardottir R, Eyfjord J, Lynch H, Ponder BA, Gayther SA, Zelada-Hedman M, Consortium at BCL: Genetic heterogeneity and penetrance analysis of the BRCA1 and BRCA2 genes in breast cancer families. The Breast Cancer Linkage Consortium. Am J Hum Genet 1998, 62:676-689

7. Antoniou A, Pharoah PD, Narod S, Risch HA, Eyfjord JE, Hopper JL, Loman N, Olsson H, Johannsson O, Borg A, Pasini B, Radice P, Manoukian S, Eccles DM, Tang N, Olah E, Anton-Culver H, Warner E, Lubinski J, Gronwald J, Gorski B, Tulinius H, Thorlacius S, Eerola $H$, Nevanlinna H, Syrjakoski K, Kallioniemi OP, Thompson D, Evans C, Peto J, Lalloo F, Evans DG, Easton DF: Average risks of breast and ovarian cancer associated with BRCA1 or BRCA2 mutations detected in case series unselected for family history: a combined analysis of 22 studies. Am J Hum Genet 2003, 72:1117-1130

8. Ford D, Easton DF, Bishop DT, Narod SA, Goldgar DE: Risks of cancer in BRCA1-mutation carriers. Breast Cancer Linkage Consortium. Lancet 1994, 343:692-695

9. King MC, Marks JH, Mandell JB: Breast and ovarian cancer risks due to inherited mutations in BRCA1 and BRCA2. Science 2003, 302:643-646

10. Chen S, Parmigiani G: Meta-analysis of BRCA1 and BRCA2 penetrance. J Clin Oncol 2007, 25:1329-1333

11. McDonnell SK, Schaid DJ, Myers JL, Grant CS, Donohue JH, Woods JE, Frost MH, Johnson JL, Sitta DL, Slezak JM, Crotty TB, Jenkins RB, Sellers TA, Hartmann LC: Efficacy of contralateral prophylactic mastectomy in women with a personal and family history of breast cancer. J Clin Oncol 2001, 19:3938-3943

12. Verhoog LC, Brekelmans CT, Seynaeve C, Meijers-Heijboer EJ, Klijn JG: Contralateral breast cancer risk is influenced by the age at onset in BRCA1-associated breast cancer. Br J Cancer 2000, 83:384-386

13. Robson M, Svahn T, McCormick B, Borgen P, Hudis CA, Norton L, Offit $\mathrm{K}$ : Appropriateness of breast-conserving treatment of breast carcinoma in women with germline mutations in BRCA1 or BRCA2: a clinic-based series. Cancer 2005, 103:44-51

14. Metcalfe KA, Lynch HT, Ghadirian P, Tung N, Olivotto IA, Foulkes WD, Warner E, Olopade O, Eisen A, Weber B, McLennan J, Sun P, Narod SA: The risk of ovarian cancer after breast cancer in BRCA1 and BRCA2 carriers. Gynecol Oncol 2005, 96:222-226
15. Brose MS, Rebbeck TR, Calzone KA, Stopfer JE, Nathanson KL, Weber BL: Cancer risk estimates for BRCA1 mutation carriers identified in a risk evaluation program. J Natl Cancer Inst 2002, 94:1365-1372

16. Thompson D, Easton D: Variation in cancer risks, by mutation position, in BRCA2 mutation carriers. Am J Hum Genet 2001, 68:410-419

17. Liede A, Karlan BY, Narod SA: Cancer risks for male carriers of germline mutations in BRCA1 or BRCA2: a review of the literature. $\mathrm{J}$ Clin Oncol 2004, 22:735-742

18. Struewing JP, Coriaty ZM, Ron E, Livoff A, Konichezky M, Cohen P Resnick MB, Lifzchiz-Mercerl B, Lew S, Iscovich J: Founder BRCA1/2 mutations among male patients with breast cancer in Israel. Am J Hum Genet 1999, 65:1800-1802

19. Ottini L, Masala G, D'Amico C, Mancini B, Saieva C, Aceto G, Gestri D, Vezzosi V, Falchetti M, De Marco M, Paglierani M, Cama A, Bianchi S, Mariani-Costantini R, Palli D: BRCA1 and BRCA2 mutation status and tumor characteristics in male breast cancer: a population-based study in Italy. Cancer Res 2003, 63:342-347

20. Frank TS, Deffenbaugh AM, Reid JE, Hulick M, Ward BE, Lingenfelter B, Gumpper KL, Scholl T, Tavtigian SV, Pruss DR, Critchfield GC: Clinical characteristics of individuals with germline mutations in BRCA1 and BRCA2: analysis of 10,000 individuals. J Clin Oncol 2002, 20:1480-1490

21. Tai $Y C$, Domchek S, Parmigiani G, Chen S: Breast cancer risk among male BRCA1 and BRCA2 mutation carriers. J Natl Cancer Inst 2007, 99:1811-1814

22. Risch HA, McLaughlin JR, Cole DE, Rosen B, Bradley L, Kwan E, Jack E, Vesprini DJ, Kuperstein G, Abrahamson JL, Fan I, Wong B, Narod SA: Prevalence and penetrance of germline BRCA1 and BRCA2 mutations in a population series of 649 women with ovarian cancer. Am J Hum Genet 2001, 68:700-710

23. Thompson D, Easton DF: Cancer incidence in BRCA1 mutation carriers. J Natl Cancer Inst 2002, 94:1358-1365

24. van Asperen CJ, Brohet RM, Meijers-Heijboer EJ, Hoogerbrugge N Verhoef S, Vasen HF, Ausems MG, Menko FH, Gomez Garcia EB, Klijn JG, Hogervorst FB, van Houwelingen JC, van't Veer LJ, Rookus MA, van Leeuwen FE: Cancer risks in BRCA2 families: estimates for sites other than breast and ovary. J Med Genet 2005, 42:711-719

25. Easton D, Thompson D, McGuffog L, Haites N, Schofield A, Scott RJ, King MC, Schubert E, Bignon Y, Stratton M, Ford D, Peto J, Eeles R, Ponder B, Gayther S, Chang-Claude J, Weber BHF, Hamann U, Osorio A, Eerola H, Nevanlinna H, Lynch HT, Narod S, Goldgar D, Lenoir G, Stoppa-Lyonnet D, Arason A, Barkardottir R, Egilsson V, Eyfjord J, Tulinius H, Bishop DT, Borg A, Loman N, Johannsson O, Olsson H, Tonin P, Foulkes W, Ghadirian P, Mes-Masson AM, Provencher D, Weber B, Devilee P, Vasen H, Cornelisse CJ, MeijersHejboer H, Klijn JGM, Brunet JS, Moslehi R, Neuhausen S, CannonAlbright L: Cancer risks in BRCA2 mutation carriers. The Breast Cancer Linkage Consortium. J Natl Cancer Inst 1999, 91:1310-1316

26. Ozcelik H, Schmocker B, Di Nicola N, Shi XH, Langer B, Moore M, Taylor BR, Narod SA, Darlington G, Andrulis IL, Gallinger S, Redston M: Germline BRCA2 6174delT mutations in Ashkenazi Jewish pancreatic cancer patients. Nat Genet 1997, 16:17-18

27. Lakhani S, Van de Vijver MJ, Jacquemier J, Anderson T, Osin P, McGuffog L, Easton D: The pathology of familial breast cancer: predictive value of immunohistochemical markers estrogen receptor, progesterone receptor, HER-2, and p53 in patients with mutations in BRCA1 and BRCA2. J Clin Oncol 2002, 20:2310-2318

28. Lakhani SR, Easton D, Stratton M: Pathology of familial breast cancer: differences between breast cancers in carriers of BRCA1 or BRCA2 mutations and sporadic cases. Breast Cancer Linkage Consortium. Lancet 1997, 349:1505-1510

29. Lakhani SR, Reis-Filho JS, Fulford L, Penault-Llorca F, van der Vijver M, Parry S, Bishop T, Benitez J, Rivas C, Bignon YJ, Chang-Claude J, Hamann U, Cornelisse CJ, Devilee P, Beckmann MW, Nestle-Kramling C, Daly PA, Haites N, Varley J, Lalloo F, Evans G, Maugard C, MeijersHeijboer H, Klijn JG, Olah E, Gusterson BA, Pilotti S, Radice P, Scherneck S, Sobol H, Jacquemier J, Wagner T, Peto J, Stratton MR, McGuffog L, Easton DF: Prediction of BRCA1 status in patients with breast cancer using estrogen receptor and basal phenotype. Clin Cancer Res 2005, 11:5175-5180

30. Lakhani SR, Jacquemier J, Sloane JP, Gusterson BA, Anderson TJ, van de Vijver MJ, Farid LM, Venter D, Antoniou A, Storfer-Isser A, 
Smyth E, Steel CM, Haites N, Scott RJ, Goldgar D, Nehausen S, Daly PA, Ormiston W, McManus R, Scherneck S, Ponder BA, Ford D, Peto J, Stoppa-Lyonnet D, Bignon YJ, Struewing JP, Spurr NK, Bishop DT, Klijn JG, Devilee P, Comelisse CJ, Lasset C, Lenoir G, Barkardottir RB, Egilsson V, Hamann U, Chang-Claude J, Sobol H, Weber B, Stratton MR, Easton DF: Multifactorial analysis of differences between sporadic breast cancers and cancers involving BRCA1 and BRCA2 mutations. J Natl Cancer Inst 1998, 90:1138-1145

31. Chappuis P, Nethercot V, Foulkes W: Clinico-pathological characteristics of BRCA1- and BRCA2-related breast cancer. Semin Surg Oncol 2000, 18:287-295

32. Palacios J, Honrado E, Osorio A, Cazorla A, Sarrio D, Barroso A, Rodriguez S, Cigudosa JC, Diez O, Alonso C, Lerma E, Sanchez L, Rivas C, Benitez J: Immunohistochemical characteristics defined by tissue microarray of hereditary breast cancer not attributable to BRCA1 or BRCA2 mutations: differences from breast carcinomas arising in BRCA1 and BRCA2 mutation carriers. Clin Cancer Res 2003, 9:3606-3614

33. Werness BA, Ramus SJ, Whittemore AS, Garlinghouse-Jones K, Oakley-Girvan I, Dicioccio RA, Tsukada Y, Ponder BA, Piver MS: Histopathology of familial ovarian tumors in women from families with and without germline BRCA1 mutations. Hum Pathol 2000, 31:1420-1424

34. Shaw PA, McLaughlin JR, Zweemer RP, Narod SA, Risch H, Verheijen RH, Ryan A, Menko FH, Kenemans P, Jacobs IJ: Histopathologic features of genetically determined ovarian cancer. Int J Gynecol Pathol 2002, 21:407-411

35. Hogg R, Friedlander M: Biology of epithelial ovarian cancer: implications for screening women at high genetic risk. J Clin Oncol 2004, 22:1315-1327

36. Boyd J, Sonada Y, Federico M, Bogomolniy F, Rhei E, Maresco D, Saigo P, Almadrones L, Barakat RR, Brown C, Chi D, Curtin J, Poyner E, Hoskins W: Clinicopathologic features of BRCA-linked and sporadic ovarian cancer. JAMA 2000, 283:2260-2265

37. Lakhani SR, Manek S, Penault-Llorca F, Flanagan A, Arnout L, Merrett S, McGuffog L, Steele D, Devilee P, Klijn JG, Meijers-Heijboer H, Radice P, Pilotti S, Nevanlinna H, Butzow R, Sobol H, Jacquemier J, Lyonet DS, Neuhausen SL, Weber B, Wagner T, Winqvist R, Bignon YJ, Monti F, Schmitt F, Lenoir G, Seitz S, Hamman U, Pharoah P, Lane G, Ponder B, Bishop DT, Easton DF: Pathology of ovarian cancers in BRCA1 and BRCA2 carriers. Clin Cancer Res 2004, 10:2473-2481

38. Gotlieb WH, Chetrit A, Menczer J, Hirsh-Yechezkel G, Lubin F, Friedman E, Modan B, Ben-Baruch G: Demographic and genetic characteristics of patients with borderline ovarian tumors as compared to early stage invasive ovarian cancer. Gynecol Oncol 2005, 97:780-783

39. Miki Y, Swensen J, Shattuck-Eidens D, Futreal PA, Harshman K, Tavtigian S, Liu Q, Cochran C, Bennett LM, Ding W, Bell R, Rosenthal J, Hussey C, Tran T, McClure M, Frye C, Hattier T, Goholami Z, Shaffer D, Stone S, Bayer S, Wray C, Bogden R, Dayananth $\mathrm{P}$, Ward J, Tonin P, Narod S, Bristow PK, Norris FH, Helvering L, Morrison P, Rosteck P, Lai M, Barrett JC, Lewis C, Neuhausen SL, Cannon-Albright L, Goldgar D, Wiseman R, Kamb A, Skolnick MH: A strong candidate for the breast and ovarian cancer susceptibility gene BRCA1. Science 1994, 266:66-71

40. Wooster R, Bignell G, Lancaster J, Swift S, Seal S, Mangion J, Collins N, Gregory S, Gumbs C, Micklem G: Identification of the breast cancer susceptibility gene BRCA2. Nature 1995, 378:789-792

41. Wooster R, Neuhausen SL, Mangion J, Quirk Y, Ford D, Collins N, Nguyen K, Seal S, Tran T, Averill D, Fields P, Marshall G, Narod S, Lenoir G, Lynch H, Feunteun J, Devilee P, Cornelisse CJ, Menko FH, Daly PA, Ormiston W, McManus R, Pye C, Lewis CM, CannonAlbright L, Peto J, Ponder BAJ, Skolnick MH, Easton DF, Goldgar $\mathrm{DE}$, Stratton M: Localization of a breast cancer susceptibility gene, BRCA2, to chromosome 13q12-13. Science 1994, 265:2088-2090

42. Narod SA, Foulkes WD: BRCA1 and BRCA2: 1994 and beyond. Nat Rev Cancer 2004, 4:665-676

43. Scully R, Chen J, Plug A, Xiao Y, Weaver D, Feunteun J, Ashley T, Livingston DM: Association of BRCA1 with Rad51 in mitotic and meiotic cells. Cell 1997, 88:265-275

44. Struewing JP, Hartge P, Wacholder S, Baker SM, Berlin M, McAdams M, Timmerman MM, Brody LC, Tucker MA: The risk of cancer associated with specific mutations of BRCA1 and BRCA2 among Ashkenazi Jews. N Engl J Med 1997, 336:1401-1408

45. Gudmundsson J, Johannesdottir G, Arason A, Bergthorsson JT,
Ingvarsson S, Egilsson V, Barkardottir RB: Frequent occurrence of BRCA2 linkage in Icelandic breast cancer families and segregation of a common BRCA2 haplotype. Am J Hum Genet 1996, 58:749-756

46. Thorlacius S, Olafsdottir G, Tryggvadottir L, Neuhausen S, Jonasson JG, Tavtigian SV, Tulinius H, Ogmundsdottir HM, Eyfjord JE: A single BRCA2 mutation in male and female breast cancer families from Iceland with varied cancer phenotypes. Nat Genet 1996, 13:117-119

47. Tonin PN, Mes-Masson AM, Futreal PA, Morgan K, Mahon M Foulkes WD, Cole DE, Provencher D, Ghadirian P, Narod SA Founder BRCA1 and BRCA2 mutations in French Canadian breast and ovarian cancer families. Am J Hum Genet 1998, 63:1341-1351

48. Simard J, Tonin P, Durocher F, Morgan K, Rommens J, Gingras S, Samson C, Leblanc JF, Belanger C, Dion F, Liu Q, Skolnick M, Goldgar D, Shattuck-Eidens D, Labrie F, Narod SA: Common origins of BRCA1 mutations in Canadian breast and ovarian cancer families. Nat Genet 1994, 8:392-398

49. Petrij-Bosch A, Peelen $T$, van Vliet M, van Eijk R, Olmer R, Drusedau M, Hogervorst FB, Hageman S, Arts PJ, Ligtenberg MJ, MeijersHeijboer H, Klijn JG, Vasen HF, Cornelisse CJ, van't Veer LJ, Bakker E, van Ommen GJ, Devilee P: BRCA1 genomic deletions are major founder mutations in Dutch breast cancer patients. Nat Genet 1997 17:341-345

50. Peelen T, van Vliet M, Petrij-Bosch A, Mieremet R, Szabo C, van den Ouweland AM, Hogervorst F, Brohet R, Ligtenberg MJ, Teugels E, van der Luijt R, van der Hout AH, Gille JJ, Pals G, Jedema I, Olmer R, van Leeuwen I, Newman B, Plandsoen M, van der Est M, Brink G, Hageman S, Arts PJ, Bakker MM, Willems HW, van der Looij E, Neyns B, Bonduelle M, Jansen R, Oosterwijk JC, Sijmons RH, Smeets HJM, Van Asperen CJ, Meijers-Heijboer H, Klijn M, de Greve $J$, King MC, Menko FH, Brunner HG, Halley D, van Ommen GJB Vasen HFA, Cornelisse CJ, van't Veer LJ, de Knijff P, Bakker E, Devilee P: A high proportion of novel mutations in BRCA1 with strong founder effects among Dutch and Belgian hereditary breast and ovarian cancer families. Am J Hum Genet 1997, 60:1041-1049

51. Mefford HC, Baumbach L, Panguluri RC, Whitfield-Broome C, Szabo C, Smith S, King MC, Dunston G, Stoppa-Lyonnet D, Arena F: Evidence for a BRCA1 founder mutation in families of West African ancestry. Am J Hum Genet 1999, 65:575-578

52. Gao Q, Tomlinson G, Das S, Cummings S, Sveen L, Fackenthal J, Schumm P, Olopade OI: Prevalence of BRCA1 and BRCA2 mutations among clinic-based African American families with breast cancer. Hum Genet 2000, 107:186-191

53. Walsh T, Casadei S, Coats KH, Swisher E, Stray SM, Higgins J, Roach KC, Mandell J, Lee MK, Ciernikova S, Foretova L, Soucek P, King MC: Spectrum of mutations in BRCA1, BRCA2, CHEK2, and TP53 in families at high risk of breast cancer. JAMA 2006, 295:1379-1388

54. Nagy R, Sweet K, Eng C: Highly penetrant hereditary cancer syndromes. Oncogene 2004, 23:6445-6470

55. Burke W, Daly M, Garber J, Botkin J, Kahn MJ, Lynch P, McTiernan A, Offit K, Perlman J, Petersen G. Thomson E, Varricchio C: Recommendations for follow-up care of individuals with an inherited predisposition to cancer. II. BRCA1 and BRCA2 Cancer Genetics Studies Consortium. JAMA 1997, 277:997-1003

56. Daly MB, Axilbund JE, Bryant E, Buys S, Eng C, Friedman S, Esserman LJ, Farrell CD, Ford JM, Graber JE, Jeter JM, Kohlmann W, Lynch PM Marcom PK, Nabell LM, Offit K, Osarogiagbon RU, Pasche B. Reiser G, Sutphen R, Weitzel JN: National Comprehensive Cancer Network: Genetic/Familial High-Risk Assessment: Breast and Ovarian Clinical Practice Guidelines. J Natl Compr Canc Netw 2006, 4:156-76

57. Saslow D, Boetes C, Burke W, Harms S, Leach MO, Lehman CD, Morris E, Pisano E, Schnall M, Sener S, Smith RA, Warner E, Yaffe M, Andrews KS, Russell CA: American Cancer Society guidelines for breast screening with MRI as an adjunct to mammography. CA Cancer J Clin 2007, 57:75-89

58. Narod SA, Brunet JS, Ghadirian P, Robson M, Heimdal K, Neuhausen SL, Stoppa-Lyonnet D, Lerman C, Pasini B, de los Rios P, Weber B, Lynch H: Tamoxifen and risk of contralateral breast cancer in BRCA1 and BRCA2 mutation carriers: a case-control study. Hereditary Breast Cancer Clinical Study Group. Lancet 2000, 356:1876-1881

59. Gronwald J, Tung N, Foulkes W, Offict K, Gershoni R, Daly M, Kim-Sing C, Olsson H, Ainsworth $P$, Eisen A, Saal H, Friedman E, 
Olopade O, Osborne M, Weitzel J, Lynch H, Ghadirian P, Lubinski J, Sun P, Narod S, Group THBCCS: Tamoxifen and contralateral breast cancer in BRCA1 and BRCA2 carriers: an update. Int $\mathrm{J}$ Cancer 2005, 118:2281-2284

60. Hartmann LC, Sellers TA, Schaid DJ, Frank TS, Soderberg CL, Sitta DL, Frost MH, Grant CS, Donohue JH, Woods JE, McDonnell SK, Vockley CW, Deffenbaugh A, Couch FJ, Jenkins RB: Efficacy of bilateral prophylactic mastectomy in BRCA1 and BRCA2 gene mutation carriers. J Natl Cancer Inst 2001, 93:1633-1637

61. Rebbeck TR, Friebel T, Lynch HT, Neuhausen SL, van't Veer L, Garber JE, Evans GR, Narod SA, Isaacs C, Matloff E, Daly MB, Olopade OI, Weber BL: Bilateral prophylactic mastectomy reduces breast cancer risk in BRCA1 and BRCA2 mutation carriers: the PROSE Study Group. J Clin Oncol 2004, 22:1055-1062

62. Meijers-Heijboer H, van Geel B, van Putten WL, Henzen-Logmans SC, Seynaeve C, Menke-Pluymers MB, Bartels CC, Verhoog LC, van den Ouweland AM, Niermeijer MF, Brekelmans CT, Klijn JG: Breast cancer after prophylactic bilateral mastectomy in women with a BRCA1 or BRCA2 mutation. N Engl J Med 2001, 345:159-164

63. Kauff ND, Satagopan JM, Robson ME, Scheuer L, Hensley M, Hudis CA, Ellis NA, Boyd J, Borgen PI, Barakat RR, Norton L, Castiel M, Nafa K, Offit K: Risk-reducing salpingo-oophorectomy in women with a BRCA1 or BRCA2 mutation. N Engl J Med 2002, 346:1609-1615

64. Rebbeck TR, Lynch HT, Neuhausen SL, Narod SA, Van't Veer L, Garber JE, Evans G, Isaacs C, Daly MB, Matloff E, Olopade OI, Weber BL: Prophylactic oophorectomy in carriers of BRCA1 or BRCA2 mutations. N Engl J Med 2002, 346:1616-1622

65. Rutter JL, Wacholder S, Chetrit A, Lubin F, Menczer J, Ebbers S, Tucker MA, Struewing JP, Hartge P: Gynecologic surgeries and risk of ovarian cancer in women with BRCA1 and BRCA2 Ashkenazi founder mutations: an Israeli population-based case-control study. J Natl Cancer Inst 2003, 95:1072-1078

66. Domchek SM, Friebel TM, Neuhausen SL, Wagner T, Evans G, Isaacs C, Garber JE, Daly MB, Eeles R, Matloff E, Tomlinson GE, Van't Veer L, Lynch HT, Olopade OI, Weber BL, Rebbeck TR: Mortality after bilateral salpingo-oophorectomy in BRCA1 and BRCA2 mutation carriers: a prospective cohort study. Lancet Oncol 2006, 7:223-229

67. Eisen A, Lubinski J, Klijn J, Moller P, Lynch HT, Offit K, Weber B, Rebbeck T, Neuhausen SL, Ghadirian P, Foulkes WD, GershoniBaruch R, Friedman E, Rennert G, Wagner T, Isaacs C, Kim-Sing C, Ainsworth $P$, Sun P, Narod SA: Breast cancer risk following bilateral oophorectomy in BRCA1 and BRCA2 mutation carriers: an international case-control study. J Clin Oncol 2005, 23:7491-7496

68. McGuire V, Felberg A, Mills M, Ostrow KL, DiCioccio R, John EM, West DW, Whittemore AS: Relation of contraceptive and reproductive history to ovarian cancer risk in carriers and noncarriers of BRCA1 gene mutations. Am J Epidemiol 2004, 160:613-618

69. Bosetti C, Negri E, Trichopoulos D, Franceschi S, Beral V, Tzonou A, Parazzini F, Greggi S, La Vecchia C: Long-term effects of oral contraceptives on ovarian cancer risk. Int J Cancer 2002, 102:262-265

70. Narod SA, Risch H, Moslehi R, Dorum A, Neuhausen S, Olsson H, Provencher D, Radice P, Evans G, Bishop S, Brunet JS, Ponder BA: Oral contraceptives and the risk of hereditary ovarian cancer. Hereditary Ovarian Cancer Clinical Study Group. N Engl J Med 1998, 339:424-428

71. McLaughlin JR, Risch HA, Lubinski J, Moller P, Ghadirian P, Lynch H, Karlan B, Fishman D, Rosen B, Neuhausen SL, Offit K, Kauff N, Domchek S, Tung N, Friedman E, Foulkes W, Sun P, Narod SA: Reproductive risk factors for ovarian cancer in carriers of BRCA1 or BRCA2 mutations: a case-control study. Lancet Oncol 2007, 8:26-34

72. Eng C: Cowden syndrome. J Genet Couns 1997, 6:181-192

73. Eng C: Will the real Cowden syndrome please stand up: revised diagnostic criteria. J Med Genet 2000, 37:828-830

74. Hanssen AM, Fryns JP: Cowden syndrome. J Med Genet 1995, 32:117-119

75. Pilarski R, Eng C: Will the real Cowden syndrome please stand up (again)? Expanding mutational and clinical spectra of the PTEN hamartoma tumor syndrome. J Med Genet 2007, 2004:323-326

76. Starink TM, van der Veen JP, Arwert F, de Waal LP, de Lange GG,
Gille JJ, Eriksson AW: The Cowden syndrome: a clinical and genetic study in 21 patients. Clin Genet 1986, 29:222-233

77. Brownstein MH, Wolf M, Bikowski JB: Cowden's disease: a cutaneous marker of breast cancer. Cancer 1978, 41:2393-2398

78. Eng C: PTEN: one gene, many syndromes. Hum Mutat 2003 22:183-198

79. Fackenthal JD, Marsh DJ, Richardson AL, Cummings SA, Eng C Robinson BG, Olopade OI: Male breast cancer in Cowden syndrome patients with germline PTEN mutations. J Med Genet 2001, 38:159-164

80. Padberg GW, Schot JD, Vielvoye GJ, Bots GT, de Beer FC: Lhermitte-Duclos disease and Cowden disease: a single phakomatosis. Ann Neurol 1991, 29:517-523

81. Eng C, Murday V, Seal S, Mohammed S, Hodgson SV, Chaudary MA, Fentiman IS, Ponder BA, Eeles RA: Cowden syndrome and Lhermitte-Duclos disease in a family: a single genetic syndrome with pleiotropy? J Med Genet 1994, 31:458-461

82. Schrager CA, Schneider D, Gruener AC, Tsou HC, Peacocke M Clinical and pathological features of breast disease in Cowden's syndrome: an underrecognized syndrome with an increased risk of breast cancer. Hum Pathol 1998, 29:47-53

83. Schrager CA, Schneider D, Gruener AC, Tsou HC, Peacocke M Similarities of cutaneous and breast pathology in Cowden's syndrome. Exp Dermatol 1998, 7:380-390

84. Liaw D, Marsh DJ, Li J, Dahia PL, Wang SI, Zheng Z, Bose S, Call KM, Tsou HC, Peacocke M, Eng C, Parsons R: Germline mutations of the PTEN gene in Cowden disease, an inherited breast and thyroid cancer syndrome. Nat Genet 1997, 16:64-67

85. Marsh DJ, Coulon V, Lunetta KL, Rocca-Serra P, Dahia PL, Zheng Z, Liaw D, Caron S, Duboue B, Lin AY, Richardson AL, Bonnetblanc JM, Bressieux JM, Cabarrot-Moreau A, Chompret A, Demange L, Eeles RA, Yahanda AM, Fearon ER, Fricker JP, Gorlin RJ, Hodgson SV, Huson S, Lacombe D, LePrat F, Odent S, Toulous C, Olopade OI, Sobol H, Tishler S, Woods CG, Robinson BG, Weber C, Parsons R, Peacocke M, Longy M, Eng C: Mutation spectrum and genotypephenotype analyses in Cowden disease and Bannayan-Zonana syndrome, two hamartoma syndromes with germline PTEN mutation. Hum Mol Genet 1998, 7:507-515

86. Steck PA, Pershouse MA, Jasser SA, Yung WK, Lin H, Ligon AH, Langford LA, Baumgard ML, Hattier T, Davis T, Frye C, Hu R, Swedlund B, Teng DH, Tavtigian SV: Identification of a candidate tumour suppressor gene. MMAC1, at chromosome 10q233 that is mutated in multiple advanced cancers. Nat Genet 1997, 15:356-362

87. Eng C: Genetics of Cowden syndrome: through the looking glass of oncology. Int J Oncol 1998, 12:701-710

88. Li DM, Sun H: TEP1, encoded by a candidate tumor suppressor locus, is a novel protein tyrosine phosphatase regulated by transforming growth factor beta. Cancer Res 1997, 57:2124-2129

89. Waite KA, Eng C: Protean PTEN: form and function. Am J Hum Genet 2002, 70:829-844

90. Sansal I, Sellers WR: The biology and clinical relevance of the PTEN tumor suppressor pathway. J Clin Oncol 2004, 22:2954-2963

91. Marsh DJ, Kum JB, Lunetta KL, Bennett MJ, Gorlin RJ, Ahmed SF, Bodurtha J, Crowe C, Curtis MA, Dasouki M, Dunn T, Feit H, Geraghty MT, Graham JM Jr, Hodgson SV, Hunter A, Korf BR, Manchester D, Miesfeldt S, Murday VA, Nathanson KL, Parisi M, Pober B, Romano C, Tolmie JL, Trembath R, Winter RM, Zackai EH, Zori RT, Weng LP, Dahia PL, Eng C: PTEN mutation spectrum and genotypephenotype correlations in Bannayan-Riley-Ruvalcaba syndrome suggest a single entity with Cowden syndrome. Hum Mol Genet 1999 8:1461-1472

92. Zhou X, Hampel H, Thiele H, Gorlin RJ, Hennekam RC, Parisi M, Winter RM, Eng C: Association of germline mutation in the PTEN tumour suppressor gene and Proteus and Proteus-like syndromes. Lancet 2001, 358:210-211

93. Sidransky D, Tokino T, Helzlsouer K, Zehnbauer B, Rausch G, Shelton B, Prestigiacomo L, Vogelstein B, Davidson N: Inherited p53 gene mutations in breast cancer. Cancer Res 1992, 52:2984-2986

94. Li FP, Fraumeni JF Jr, Mulvihill JJ, Blattner WA, Dreyfus MG, Tucker MA, Miller RW: A cancer family syndrome in twenty-four kindreds. Cancer Res 1988, 48:5358-5362

95. Li FP, Fraumeni JF Jr: Soft-tissue sarcomas, breast cancer, and other neoplasms. A familial syndrome? Ann Intern Med 1969, 71:747-752

96. Lynch HT, Mulcahy GM, Harris RE, Guirgis HA, Lynch JF: Genetic 
and pathologic findings in a kindred with hereditary sarcoma, breast cancer, brain tumors, leukemia, lung, laryngeal, and adrenal cortical carcinoma. Cancer 1978, 41:2055-2064

97. Malkin D, Li FP, Strong LC, Fraumeni JF Jr, Nelson CE, Kim DH, Kassel J, Gryka MA, Bischoff FZ, Tainsky MA, Friend SH: Germ line p53 mutations in a familial syndrome of breast cancer, sarcomas, and other neoplasms. Science 1990, 250:1233-1238

98. Nichols KE, Malkin D, Garber JE, Fraumeni JF Jr, Li FP: Germ-line p53 mutations predispose to a wide spectrum of early-onset cancers. Cancer Epidemiol Biomarkers Prev 2001, 10:83-87

99. Hartley AL, Birch JM, Marsden HB, Harris M: Malignant melanoma in families of children with osteosarcoma, chondrosarcoma, and adrenal cortical carcinoma. J Med Genet 1987, 24:664-668

100. Jay M, McCartney AC: Familial malignant melanoma of the uvea and p53: a Victorian detective story. Surv Ophthalmol 1993, 37:457-462

101. Birch JM, Alston RD, McNally RJ, Evans DG, Kelsey AM, Harris M, Eden OB, Varley JM: Relative frequency and morphology of cancers in carriers of germline TP53 mutations. Oncogene 2001, 20:4621-4628

102. Hwang SJ, Lozano G, Amos Cl, Strong LC: Germline p53 mutations in a cohort with childhood sarcoma: sex differences in cancer risk. Am J Hum Genet 2003, 72:975-983

103. Lustbader ED, Williams WR, Bondy ML, Strom S, Strong LC: Segregation analysis of cancer in families of childhood soft-tissue-sarcoma patients. Am J Hum Genet 1992, 51:344-356

104. Hisada M, Garber JE, Fung CY, Fraumeni JF Jr, Li FP: Multiple primary cancers in families with Li-Fraumeni syndrome. J Natl Cancer Inst 1998, 90:606-611

105. Chompret A, Brugieres L, Ronsin M, Gardes M, Dessarps-Freichey F, Abel A, Hua D, Ligot L, Dondon MG, Bressac-de Paillerets B, Frebourg T, Lemerle J, Bonaiti-Pellie C, Feunteun J: P53 germline mutations in childhood cancers and cancer risk for carrier individuals. Br J Cancer 2000, 82:1932-1937

106. Le Bihan C, Bonaiti-Pellie C: A method for estimating cancer risk in p53 mutation carriers. Cancer Detect Prev 1994, 18:171-178

107. Birch JM, Hartley AL, Tricker KJ, Prosser J, Condie A, Kelsey AM, Harris M, Jones PH, Binchy A, Crowther D, Craft AW, Eden OB, Evans GR, Thompson E, Mann JR, Martin J, Mitchell ELD, Santibanez-Koref MF: Prevalence and diversity of constitutional mutations in the p53 gene among 21 Li-Fraumeni families. Cancer Res 1994, 54:1298-1304

108. Eeles RA: Germline mutations in the TP53 gene. Cancer Surv 1995, 25:101-124

109. Chompret A, Abel A, Stoppa-Lyonnet D, Brugieres L, Pages S, Feunteun J, Bonaiti-Pellie C: Sensitivity and predictive value of criteria for p53 germline mutation screening. J Med Genet 2001, 38:43-47

110. Srivastava S, Zou ZQ, Pirollo K, Blattner W, Chang EH: Germ-line transmission of a mutated p53 gene in a cancer-prone family with Li-Fraumeni syndrome. Nature 1990, 348:747-749

111. Varley JM, McGown G, Thorncroft M, Santibanez-Koref MF, Kelsey AM, Tricker KJ, Evans DG, Birch JM: Germ-line mutations of TP53 in Li-Fraumeni families: an extended study of 39 families. Cancer Res 1997, 57:3245-3252

112. Levine AJ: p53, the cellular gatekeeper for growth and division. Cell 1997, 88:323-331

113. Lane DP: Cancer. p53, guardian of the genome. Nature 1992, 358:15-16

114. Soussi T, Caron de Fromentel C, May P: Structural aspects of the p53 protein in relation to gene evolution. Oncogene 1990, 5:945-952

115. Varley JM, Evans DG, Birch JM: Li-Fraumeni syndrome-a molecular and clinical review. Br J Cancer 1997, 76:1-14

116. Frebourg T, Barbier N, Yan YX, Garber JE, Dreyfus M, Fraumeni J Jr, Li FP, Friend SH: Germ-line p53 mutations in 15 families with LiFraumeni syndrome. Am J Hum Genet 1995, 56:608-615

117. Greenblatt MS, Bennett WP, Hollstein M, Harris CC: Mutations in the p53 tumor suppressor gene: clues to cancer etiology and molecular pathogenesis. Cancer Res 1994, 54:4855-4878

118. Brugières L, Gardes M, Moutou C, Chompret A, Meresse V, Martin A, Poisson N, Flamant F, Bonaiti-Pellie C, Lemerle J, Feunteun J: Screening for germ line p53 mutations in children with malignant tumors and a family history of cancer. Cancer Res 1993, 53:452-455

119. Bougeard G, Limacher JM, Martin C, Charbonnier F, Killian A, Delattre $\mathrm{O}$, Longy $\mathrm{M}$, Jonveaux $\mathrm{P}$, Fricker JP, Stoppa-Lyonnet $\mathrm{D}$, Flaman JM, Frebourg T: Detection of 11 germline inactivating TP53 mutations and absence of TP63 and HCHK2 mutations in 17 French families with Li-Fraumeni or Li-Fraumeni-like syndrome. J Med Genet 2001, 38:253-257

120. Varley J, Evans DG, Birch JM: Li-Fraumeni syndrome-a molecular and clinical review. Br J Cancer. 1997, 76:1-14

121. Vahteristo $P$, Bartkova J, Eerola H, Syrjakoski K, Ojala S, Kilpivaara O, Tamminen A, Kononen J, Aittomaki K, Heikkila P, Holli K, Blomqvist C, Bartek J, Kallioniemi OP, Nevanlinna H: A CHEK2 genetic variant contributing to a substantial fraction of familial breast cancer. Am J Hum Genet 2002, 71:432-438

122. Lee SB, Kim SH, Bell DW, Wahrer DC, Schiripo TA, Jorczak MM, Sgroi DC, Garber JE, Li FP, Nichols KE, Varley JM, Godwin AK, Shannon KM, Harlow E, Haber DA: Destabilization of CHK2 by a missense mutation associated with Li-Fraumeni syndrome. Cancer Res 2001, 61:8062-8067

123. Bell DW, Varley JM, Szydlo TE, Kang DH, Wahrer DC, Shannon KE, Lubratovich M, Verselis SJ, Isselbacher KJ, Fraumeni JF, Birch JM Li FP, Garber JE, Haber DA: Heterozygous germ line hCHK2 mutations in Li-Fraumeni syndrome. Science 1999, 286:2528-2531

124. Vahteristo $P$, Tamminen $A$, Karvinen $P$, Eerola $H$, Eklund $C$, Aaltonen LA, Blomqvist C, Aittomaki K, Nevanlinna H: p53, CHK2, and CHK1 genes in Finnish families with Li-Fraumeni syndrome: further evidence of $\mathrm{CHK} 2$ in inherited cancer predisposition. Cancer Res 2001, 61:5718-5722

125. Royds JA, Lacopetta B: p53 and disease: when the guardian angel fails. Cell Death Differ 2006, 13:1017-1026

126. Allinen M, Huusko P, Mantyniemi S, Launonen V, Winqvist R: Mutation analysis of the $\mathrm{CHK} 2$ gene in families with hereditary breast cancer. Br J Cancer 2001, 85:209-212

127. Siddiqui R, Onel K, Facio F, Nafa K, Diaz LR, Kauff N, Huang H, Robson M, Ellis N, Offit K: The TP53 mutational spectrum and frequency of CHEK2*1100delC in Li-Fraumeni-like kindreds. Fam Cancer 2005, 4:177-181

128. Limacher JM, Frebourg T, Natarajan-Ame S, Bergerat JP: Two metachronous tumors in the radiotherapy fields of a patient with $\mathrm{Li}$ Fraumeni syndrome. Int J Cancer 2001, 96:238-242

129. Nutting C, Camplejohn RS, Gilchrist R, Tait D, Blake P, Knee G, Yao WQ, Ross G, Fisher C, Eeles R: A patient with 17 primary tumours and a germ line mutation in TP53: tumour induction by adjuvant therapy? Clin Oncol (R Coll Radiol) 2000, 12:300-304

130. Trepanier A, Ahrens M, McKinnon W, Peters J, Stopfer J, Grumet SC, Manley S, Culver JO, Acton R, Larsen-Haidle J, Correia LA Bennett R, Pettersen B, Ferlita TD, Costalas JW, Hunt K, Donlon S, Skrzynia C, Farrell C, Callif-Daley F, Vockley CW: Genetic cancer risk assessment and counseling: recommendations of the Nationa Society of Genetic Counselors. J Genet Couns 2004, 13:83-114

131. Allain D: Genetic counseling and testing for hereditary breast and colorectal cancer syndromes: an overview. Contemp Oncol 2005 $1: 1-10$

132. Bennett RL, Steinhaus KA, Uhrich SB, O'Sullivan CK, Resta RG, Lochner-Doyle D, Markel DS, Vincent V, Hamanishi J: Recommendations for standardized human pedigree nomenclature. Pedigree Standardization Task Force of the National Society of Genetic Counselors. Am J Hum Genet 1995, 56:745-752

133. Love RR, Evans AM, Josten DM: The accuracy of patient reports of a family history of cancer. J Chronic Dis 1985, 38:289-293

134. Theis B, Boyd N, Lockwood G, Tritchler D: Accuracy of family cancer history in breast cancer patients. Eur J Cancer Prev 1994 3:321-327

135. Douglas FS, O'Dair LC, Robinson M, Evans DG, Lynch SA: The accuracy of diagnoses as reported in families with cancer: a retrospective study. J Med Genet 1999, 36:309-312

136. Bennett RL, Hampel HL, Mandell JB, Marks JH: Genetic counselors: translating genomic science into clinical practice. J Clin Invest 2003 112:1274-1279

137. Gail MH, Brinton LA, Byar DP, Corle DK, Green SB, Schairer C, Mulvihill JJ: Projecting individualized probabilities of developing breast cancer for white females who are being examined annually. J Natl Cancer Inst 1989, 81:1879-1886

138. Claus EB, Risch N, Thompson WD: Autosomal dominant inheritance of early-onset breast cancer. Implications for risk prediction. Cancer 1994, 73:643-651

139. Parmigiani G, Berry D, Aguilar O: Determining carrier probabilities 
for breast cancer-susceptibility genes BRCA1 and BRCA2. Am $J$ Hum Genet 1998, 62:145-158

140. Couch FJ, DeShano ML, Blackwood MA, Calzone K, Stopfer J, Campeau L, Ganguly A, Rebbeck T, Weber BL: BRCA1 mutations in women attending clinics that evaluate the risk of breast cancer. N Engl J Med 1997, 336:1409-1415

141. Shattuck-Eidens D, Oliphant A, McClure M, McBride C, Gupte J, Rubano T, Pruss D, Tavtigian SV, Teng DH, Adey N, Staebell M, Gumpper K, Lundstrom R, Hulick M, Kelly M, Holmen J, Lingenfelter B, Manley S, Fujimura F, Luce M, Ward B, Cannon-Albright L, Steele L, Offit K, Gilewski T, Norton L, Brown K, Schulz C, Hampel H, Schluger A, Giulotto E, Zoli W, Ravaioli A, Nevanlinna H, Pyrhonen S, Rowley PT, Loader S, Osborne MP, Daly M, Tepler I, Weinstein PL, Scalia JL, Michaelson R, Scott RJ, Radice P, Pierotti MA, Garber JE, Isaacs C, Peshkin B, Lippman ME, Dosik MH, Caligo MA, Greenstein RM, Pilarski R, Weber B, Burgemeister R, Frank TS, Skolnick $\mathrm{MH}$, Thomas A: BRCA1 sequence analysis in women at high risk for susceptibility mutations. Risk factor analysis and implications for genetic testing. JAMA 1997, 278:1242-1250

142. Tyrer J, Duffy SW, Cuzick J: A breast cancer prediction model incorporating familial and personal risk factors. Stat Med 2004, 23:1111-1130

143. Kang HH, Williams R, Leary J, Ringland C, Kirk J, Ward R: Evaluation of models to predict BRCA germline mutations. $\mathrm{Br} \mathrm{J}$ Cancer 2006, 95:914-920

144. Barcenas CH, Hosain GM, Arun B, Zong J, Zhou X, Chen J, Cortada JM, Mills GB, Tomlinson GE, Miller AR, Strong LC, Amos Cl: Assessing BRCA carrier probabilities in extended families. J Clin Oncol 2006, 24:354-360

145. James PA, Doherty R, Harris M, Mukesh BN, Milner A, Young MA, Scott C: Optimal selection of individuals for BRCA mutation testing: a comparison of available methods. J Clin Oncol 2006, 24:707-715

146. Hopwood P: Psychological issues in cancer genetics: current research and future priorities. Patient Educ Couns 1997, 32:19-31

147. Biesecker BB: Psychological issues in cancer genetics. Semin Oncol Nurs 1997, 13:129-134

148. Biesecker BB, Ishibe N, Hadley DW, Giambarresi TR, Kase RG, Lerman C, Struewing JP: Psychosocial factors predicting BRCA1/ BRCA2 testing decisions in members of hereditary breast and ovarian cancer families. Am J Med Genet 2000, 93:257-263

149. Lerman C, Croyle RT: Emotional and behavioral responses to genetic testing for susceptibility to cancer. Oncology (Williston Park) 1996, 10:191-200

150. Offit K, Bertagnolli MM, Bombard AT, Come S, Eng C, Garber JE, Joffe S, Greene MH, Tucker MA, Gruber SB, Guillem JG, Robson M, Halberg FE, Hampel H, Olopade OI, Rieger PT, Rodriquez-Bigas MG, Tomlinson G, Watson MS, Weber BL, Weitzel J, Wiesner GL: American Society of Clinical Oncology policy statement update: genetic testing for cancer susceptibility. J Clin Oncol 2003, 21:2397-2406
151. Foundation ACoMG: Genetic Susceptibility to Breast and Ovarian Cancer: Assessment, Counseling and Testing Guidelines. New York, American College of Medical Genetics Foundation, 1999

152. Smith A, Moran A, Boyd MC, Bulman M, Shenton A, Smith L, Iddenden R, Woodward ER, Lalloo F, Maher ER, Evans DG: Phenocopies in BRCA1 and BRCA2 families: evidence for modifier genes and implications for screening. J Med Genet 2007 44:10-15

153. Rowan E, Poll A, Narod SA: A prospective study of breast cancer risk in relatives of BRCA1/BRCA2 mutation carriers. J Med Genet 2007, 44:e89; author reply e88

154. Gronwald J, Cybulski C, Lubinski J, Narod SA: Phenocopies in breast cancer 1 (BRCA1) families: implications for genetic counselling. J Med Genet 2007, 44:e76

155. van Dijk S, van Asperen CJ, Jacobi CE, Vink GR, Tibben A, Breuning $\mathrm{MH}$, Otten W: Variants of uncertain clinical significance as a result of BRCA1/2 testing: impact of an ambiguous breast cancer risk message. Genet Test 2004, 8:235-239

156. Schwartz MD, Peshkin BN, Hughes C, Main D, Isaacs C, Lerman C: Impact of BRCA1/BRCA2 mutation testing on psychologic distress in a clinic-based sample. J Clin Oncol 2002, 20:514-520

157. Croyle RT, Smith KR, Botkin JR, Baty B, Nash J: Psychological responses to BRCA1 mutation testing: preliminary findings. Health Psychol 1997, 16:63-72

158. Bredart A, Autier P, Audisio RA, Geragthy J: Psycho-social aspects of breast cancer susceptibility testing: a literature review. Eur $J$ Cancer Care (Engl) 1998, 7:174-180

159. Lerman C, Hughes C, Lemon SJ, Main D, Snyder C, Durham C, Narod S, Lynch HT: What you don't know can hurt you: adverse psychologic effects in members of BRCA1-linked and BRCA2-linked families who decline genetic testing. J Clin Oncol 1998, 16:1650-1654

160. Lerman C, Croyle R: Psychological issues in genetic testing for breast cancer susceptibility. Arch Intern Med 1994, 154:609-616

161. Biesecker BB, Boehnke M, Calzone K, Markel DS, Garber JE, Collins FS, Weber BL: Genetic counseling for families with inherited susceptibility to breast and ovarian cancer. JAMA 1993, 269:1970-1974

162. Smith KR, West JA, Croyle RT, Botkin JR: Familial context of genetic testing for cancer susceptibility: moderating effect of siblings' test results on psychological distress one to two weeks after BRCA1 mutation testing. Cancer Epidemiol Biomarkers Prev 1999, 8:385-392

163. Hall MA, Rich SS: Laws restricting health insurers' use of genetic information: impact on genetic discrimination. Am J Hum Genet 2000, 66:293-307

164. Lapham EV, Kozma C, Weiss JO: Genetic discrimination: perspectives of consumers. Science 1996, 274:621-624

165. Health Insurance Portability and Accountability Act, Pub L 1996, 110:104-191 